\title{
Antioxidant metabolism in coffee (Coffea arabica L.) plants in response to nitrogen supply
}

\author{
André R. Reis · José L. Favarin • \\ Priscila L. Gratão • Flávia R. Capaldi • \\ Ricardo A. Azevedo
}

Received: 18 June 2015/Accepted: 24 October 2015/Published online: 12 November 2015

(C) Brazilian Society of Plant Physiology 2015

\begin{abstract}
Nitrogen (N) is the main element required for plant development. $\mathrm{N}$ fertilization interferes directly in $\mathrm{N}$ content in tissues, antioxidant systems, chlorophyll content and photosynthesis. We investigated the action of three levels of $\mathrm{N}(0,150$ and $300 \mathrm{~kg} \mathrm{~N} \mathrm{ha}^{-1}$ ) in coffee (Coffea arabica L.) cv. Catuaí Vermelho IAC 44 leaves of plants during distinct fruit development stages (from pinhead drop to dried fruit). Leaf $\mathrm{N}$ content, net photosynthesis, chlorophyll content, total soluble protein and the activities of catalase, superoxide dismutase, guaiacol peroxidase and ascorbate peroxidase were analyzed.
\end{abstract}

\footnotetext{
A. R. Reis $(\bowtie)$

Engenharia de Biossistemas, Universidade Estadual Paulista - UNESP, Tupã, SP CEP 17602-496, Brazil e-mail: andrereis@tupa.unesp.br

\section{J. L. Favarin}

Departamento de Agricultura, Escola Superior de Agricultura "Luiz de Queiroz", Universidade de São Paulo, Av. Pádua Dias, 11, Piracicaba,

SP CEP 13418-900, Brazil

\section{P. L. Gratão}

Departamento de Biologia Aplicada à Agropecuária, Faculdade de Ciências Agrárias e Veterinárias, Universidade Estadual Paulista - UNESP, Jaboticabal, SP CEP 14884-900, Brazil

F. R. Capaldi · R. A. Azevedo

Departamento de Genética, Escola Superior de Agricultura "Luiz de Queiroz", Universidade de São Paulo, Av. Pádua Dias, 11, Piracicaba,

SP CEP 13418-900, Brazil
}

Leaf $\mathrm{N}$ content, net photosynthesis, chlorophyll and protein content increased significantly with $\mathrm{N}$ supply ( $\mathrm{N}$ deficient plants exhibited visual symptoms of chlorosis). Antioxidant enzymes showed increased specific activities during fruit development, and decreases with $\mathrm{N}$ fertilization, being higher in absence of $\mathrm{N}$. We identified two bands of Mn-SOD with increased activities and one of $\mathrm{Fe}-\mathrm{SOD}$, but they did not exhibit high SOD activity remaining essentially constant. Curiously, $\mathrm{Cu} / \mathrm{Zn}-\mathrm{SOD}$ isoenzymes were not detected, despite the fact that they are frequently abundant in plants. A relationship between $\mathrm{N}$ fertilization and antioxidant enzyme activities were founded in coffee leaves during fruit development indicating high activity of enzymatic antioxidant system during the coffee fruit ripening stage.

Keywords Antioxidants · Oxidative stress · Plant nutrition $\cdot$ Coffea arabica $\cdot$ Nitrogen nutrition

\section{Introduction}

Despite being a species originating in shaded environments, coffee typically has high yields in sunny environments, but high management fertilization is required, especially in $\mathrm{N}$ (Pompelli et al. 2010). Nitrogen $(\mathrm{N})$ is the main essential nutrient for the growth and development of plant species (Lea and Azevedo 2006, 2007; Andrews et al. 2011, 2013; Neto et al. 2015). Grain yield increases linearly with the 
levels of $\mathrm{N}$ fertilizers applied to plants, which is a primordial nutrient responsible for crop productivity (Reis et al. 2011). Therefore, a better understanding of how plants respond to $\mathrm{N}$ supply is required for several reasons (Carswell et al. 2003), and many traits have been studied to improve this understanding, for example chlorophyll concentration, plant height, timing of leaf senescence, activities of enzymes controlling the assimilation of $\mathrm{N}$ and quantitative trait loci (Majerowicz et al. 2002; Ray et al. 2003; Andrews et al. 2007). In N fertilization experiments, the reduction in plant height, leaf area index and biomass production have been reported in N-deficient coffee plants (Da Matta et al. 2002; Netto et al. 2005; Fenilli et al. 2007; Reis et al. 2009a, b, 2011; Neto et al. 2011). This is because insufficient $\mathrm{N}$ input leads to the reduction in plant growth that should be attributed primarily to reduce photosynthesis (Chen et al. 2013). Leaves with high $\mathrm{N}$ content have a higher maximum net photosynthesis rate and higher carboxylation efficiency in saturation light with limiting carbon dioxide supply than those in $\mathrm{N}$-deficient plants (Andrews et al. 2009). However, these photosynthetic characteristics increase curvilinearly with increasing levels of protein and consequently the rate of carbon dioxide assimilation per unit of $\mathrm{N}$ is lower in leaves with high $\mathrm{N}$ content than with low $\mathrm{N}$ content (Da Matta et al. 1999; Lawlor et al. 2001; Da Matta et al. 2002; Reis et al. 2006).

Plants under $\mathrm{N}$ deficiency lead to reprogramming their primary and secondary metabolism (Kováčik and Bačkor 2007). Senescence and nutrient remobilization from leaves to grains during ripening stage are common phenomena in coffee plants, independent of N levels (Barros et al. 1999; Reis et al. 2006, 2009a, b) and oxidative stress share common symptoms, like loss of chloroplastic pigments and proteins, lipid peroxidation and membrane alterations, leading to a progressive decrease in photosynthetic capacity (Cassano et al. 1994; Carvalho et al. 2011). However, in N deficiency situations, these processes can occur ealier (Camargo et al. 2011). In addition, Logan et al. (1999) reported an increase in activities of antioxidant enzymes in $\mathrm{N}$-deficient spinach plants.

An adequate $\mathrm{N}$ nutritional status might induce the antioxidant systems to prevent damage on photosynthesis (Medici et al. 2004). To protect the photosynthetic apparatus from oxidative stress, plants must dissipate the excessive light energy (Carvalho et al.
2011), which can be achieved by the down-regulation of photochemical efficiency via xanthophyll cycle (Demming-Adams et al. 1996) or by maintenance of electron flux involving alternative pathways such as photorespiration and the Mehler peroxidase reaction (Asada 1999). However, both pathways lead to an increase in reactive oxygen species (ROS) generation.

ROS are highly reactive and cytotoxic to all organisms that their production must be minimized (Gratão et al. 2005; Ghelfi et al. 2011; Gill et al. 2013; $\mathrm{Su}$ et al. 2014). The accumulation of ROS in cells is usually low but under adverse environmental factors the production of ROS may be enhanced (Fidalgo et al. 2004; Monteiro et al. 2011; Cia et al. 2012). Therefore, in order to cope with ROS production within the cell, plants have a complex enzymatic antioxidant system that includes key enzymes in cellular detoxification, such as SOD (EC 1.15.1.1), which dismutates $\mathrm{O}^{-2}$ to $\mathrm{H}_{2} \mathrm{O}_{2}$ which may be detoxified to $\mathrm{H}_{2} \mathrm{O}$ by ascorbate peroxidase (APX) (EC 1.11.1.11), catalase (CAT) (EC 1.11.1.6) and guaiacol peroxidase (GPOX) (EC 1.11.1.7) (Resende et al. 2012; Dourado et al. 2013; Gratão et al. 2015). SOD isoenzymes are usually present in distinct cell compartments; for instance, chloroplasts contain basically $\mathrm{Cu} / \mathrm{Zn}-\mathrm{SOD}$ and $\mathrm{Fe}-\mathrm{SOD}$ isoenzymes, whereas in mitochondria only the Mn-SOD isoenzyme has been clearly localized (Alscher et al. 2002; Gratão et al. 2005). In peroxisomes, both $\mathrm{Cu} / \mathrm{Zn}-\mathrm{SOD}$ and Mn-SOD have been found either as soluble proteins in the organelle matrix or bound to membranes in the case of Mn-SOD (del Río et al. 2003).

There is a lack of information regarding the role of $\mathrm{N}$ on antioxidant stress responses in coffee plants (Gomes-Junior et al. 2007; Rendón et al. 2013). To our knowledge, no research has been carried out so far to specifically examine the antioxidant metabolism and the photosynthetic induction property of coffee leaves in relation to $\mathrm{N}$ fertilizer management under field conditions. In this study, changes due to $\mathrm{N}$ fertilizer were described in relation to antioxidant enzymes such as SOD, CAT, APX and GPOX, nutrient concentration and photosynthesis in coffee leaves during fruit development stages (from pinhead drop to dried fruit).

The aim of this study was to evaluate the response of net photosynthesis, chlorophyll content, protein and antioxidant enzymes in coffee leaves under different $\mathrm{N}$ supply and at different fruit developmental stages, establishing a possible relationship between different 
levels of $\mathrm{N}$ on the activation key of the cellular antioxidant enzymes system.

\section{Materials and methods}

\subsection{Site description and experimental design}

The experiment was carried out in the experimental farm of the University of São Paulo (USP/ESALQ), at Piracicaba, São Paulo State, Brazil $\left(22^{\circ} 42^{\prime}\right.$ S, $47^{\circ} 38^{\prime} \mathrm{W}$ and $580 \mathrm{~m}$ of altitude). Coffee plants (Coffea arabica L.) cv. Catuaí Vermelho IAC-44 were used, from a 6-year-old coffee orchard, spaced $1.75 \mathrm{~m}$ between rows and $0.75 \mathrm{~m}$ between plants (density of 7.633 plants per hectare). The region is characterized as a Cwa type climate, or tropical of altitude, with annual average temperatures of $21.1{ }^{\circ} \mathrm{C}$, and mean rainfall of $1.257 \mathrm{~mm}$. The raining period occurs between October and March and the dry period between June and September. The climate data was daily monitored by the computerized agrometeorological station of USP/ ESALQ setting at the experiment location.

The soil in the experimental area is classified as a neutroferric Red Nitosol, moderate A horizon and clayey texture, which chemical attributes were determined in samples from 0 to $200 \mathrm{~mm}$ depth. The soil analysis results were: $\mathrm{pH}\left(\mathrm{CaCl}_{2}\right): 5.3 ; \mathrm{OM}: 31 \mathrm{~g} \mathrm{dm}^{-3}$; $\mathrm{P}$ (resin): $8 \mathrm{mg} \mathrm{dm}^{-3}$; K: $4.3 \mathrm{mmol}_{\mathrm{c}} \mathrm{dm}^{-3}$; Ca: 29 $\mathrm{mmol}_{\mathrm{c}} \mathrm{dm}^{-3} ; \mathrm{Mg}: 20 \mathrm{mmol}_{\mathrm{c}} \mathrm{dm}^{-3} ; \mathrm{H}+\mathrm{Al}: 30$ $\mathrm{mmol}_{\mathrm{c}} \mathrm{dm}^{-3}$; CEC: $83.1 \mathrm{mmol}_{\mathrm{c}} \mathrm{dm}^{-3}$; and base saturation: $64 \%$.

The experimental design was in randomized complete blocks arranged in a $3 \times 6$ factorial with five replications. The treatments consisted of three levels of $\mathrm{N}$ applied as ammonium sulfate: T1: absence of $\mathrm{N}$ fertilization, T2: $150 \mathrm{~kg} \mathrm{~N}^{-1}$ and T3: $300 \mathrm{~kg} \mathrm{~N}^{-1}$. Six periods of evaluation during fruit developmental stages were considered: pinhead drop, rapid expansion, ripening, green, cherry and dried fruit. The highest $\mathrm{N}$ level ( $\mathrm{T} 3=300 \mathrm{~kg} \mathrm{~N} \mathrm{ha}^{-1}$ ) was estimated based on the yield expectancy (Reis et al. 2006) and an intermediate level of $\mathrm{N}$ fertilization was considered as half the maximum dosage (T2: $150 \mathrm{~kg} \mathrm{~N} \mathrm{ha}^{-1}$ ). In addition, $300 \mathrm{~kg} \mathrm{ha}^{-1}$ of potassium (applied as $\mathrm{KCl}$ ) was applied split in two applications, $150 \mathrm{~kg} \mathrm{ha}^{-1}$ in November, 2005 and in January, 2006. The levels of fertilizer were based on the expectation of yield and official recommendation for coffee plants cultivated in São Paulo State (Brazil).

\subsection{Nitrogen content determination}

For $\mathrm{N}$ analysis, coffee leaves samples were obtained for each plot, consisting of 50 leaves removed from the third leaf pairs, starting at the end of the branches in the upper third of the plant (Reis et al. 2011). Leaves were dried in a forced-air oven at $65{ }^{\circ} \mathrm{C}$ during $48 \mathrm{~h}$ and ground. Thereafter, the samples were digested and chemically analyzed. Total-N was determined by the Kjeldahl method, which consist in the sulfuric digestion of the plant material to decompose the organic-N into ammonium, which is then converted to ammonia, distilled, and the amount of ammonia was determined by back-titration (Reis et al. 2009a).

\subsection{Measurement of photosynthesis}

Photosynthetic parameters were estimated from three plants per plot in fully expanded leaves on the third or fourth leaf pairs from the apex on lateral branches in the upper third of the plant, as described by Reis et al. (2009b). During the measurements, air relative humidity was about $80 \%$ and leaf temperature ranged from 22 to $24{ }^{\circ} \mathrm{C}$. Carbon dioxide assimilation was measured in the morning under artificial, saturating photosynthetic photon flux (PPF: $0.85-0.90 \mathrm{mmol} \mathrm{m}^{-2} \mathrm{~s}^{-1}$ ) supplied by two $1000 \mathrm{~W}$ halogen tubes at an ambient $\mathrm{CO}_{2}$ concentration of about $355 \mu \mathrm{mol} \mathrm{L}{ }^{-1}$, with a portable photosynthesis meter (PPS-model LI-6400, Li-Cor, Inc., Lincoln, NE, USA). In general, maximum rates occurred near 08:00 am (solar time) throughout the warm, rainy season, and around mid-morning during the cool, dry season. Measurements were taken throughout a cloudless day during fruit developmental stages using the same PPF described above.

\subsection{Chlorophyll extraction}

For the analysis of chlorophyll content, about 15 leaves were removed from the third leaf pairs, starting at the end of the branches in the upper third of the plant. The leaf disc was cut into fine strips and placed in a test tube containing $5 \mathrm{~mL}$ acetone $80 \%$ (v/v: acetone/water). Extracted in the dark, a $3 \mathrm{~mL}$ aliquot was analyzed spectrophotometrically at 645 and $663 \mu \mathrm{m}$. The total chlorophyll levels were determined according to the equation proposed by Arnon (1949). 


\subsection{Enzyme extraction and assays}

For enzyme extraction, the coffee leaves were collected directly into liquid $\mathrm{N}$ and stored at $-80{ }^{\circ} \mathrm{C}$ for further analysis. Compound samples were obtained for each plot, consisting of 10 leaves removed from the third leaf pairs, starting at the end of the branches in the upper third of the plant. The following steps were carried out at $4{ }^{\circ} \mathrm{C}$ unless stated otherwise. The coffee leaves were homogenized (2:1 - buffer volume:fresh weight) in a mortar with a pestle with $100 \mathrm{mM}$ potassium phosphate buffer ( $\mathrm{pH} 7.5$ ) containing $1 \mathrm{mM}$ ethylenedinitrilotetraacetic acid (EDTA), $3 \mathrm{mM} \beta$-mercaptoethanol and $5 \%$ (w/v) insoluble polyvinylpolypyrrolidone (PVPP). The homogenate was centrifuged at $10,000 \times g$ for $30 \mathrm{~min}$ and the supernatant was kept stored in separate aliquots at $-80{ }^{\circ} \mathrm{C}$, prior to CAT, APX, GPOX and SOD analyses (Azevedo et al. 1998).

The total protein concentration was determined by the method of Bradford (1976) using bovine serum albumin as a standard (Bio-Rad Protein Dye Reagent).

\subsection{Polyacrylamide gel electrophoresis (PAGE) and SOD activity staining}

Electrophoretic analysis was carried out under nondenaturing condition in $9 \%$ polyacrylamide gels, followed by SOD activity staining as described by Garcia et al. (2006), with equal amounts of protein $(60 \mu \mathrm{g})$ being loaded on to each lane. SOD activity was determined as described by Azevedo et al. (1998). The gel was rinsed in distilled-deionized water and incubated in the dark for $30 \mathrm{~min}$ at room temperature in a reaction mixture containing $50 \mathrm{mM}$ potassium phosphate buffer ( $\mathrm{pH} 7.8$ ), $1 \mathrm{mM}$ EDTA, $0.05 \mathrm{mM}$ riboflavin, $0.1 \mathrm{mM}$ nitrobluetetrazolium, and $0.3 \%$ $\mathrm{N}, \mathrm{N}, \mathrm{N}^{\prime}, \mathrm{N}^{\prime}$ tetramethyl ethylenediamine (TEMED). At the end of this period, the reaction mixture was poured off, the gel rinsed with distilled-deionized water and then illuminated in water until the development of colourless bands of SOD activity on the purple-stained gel. A standard sample of bovine SOD (Sigma Chemical Co.) was applied to all gels to be used as a positive control for SOD activity.

\subsection{SOD densitometry analyses}

SOD isoenzymes bands were observed following the staining of PAGE $9 \%$ for enzyme activity and the intensity of the band was recorded according to a densitometry analysis through the use of Kodak Digital Science-1D (Image Analysis Software version 3.0.1).

\subsection{SOD isoenzymes}

An identical assay was carried out in parallel to classify the SOD isoenzymes by testing using potassium cyanide $(\mathrm{KCN})$ and hydrogen peroxide $\left(\mathrm{H}_{2} \mathrm{O}_{2}\right)$ as inhibitors of specific activities (Vitória et al. 2001). SOD isoenzymes were classified as described previously by Azevedo et al. (1998) according to their sensitivity to $\mathrm{KCN}(\mathrm{Cu} / \mathrm{Zn}-\mathrm{SOD}$ inhibitor) and/or $\mathrm{H}_{2} \mathrm{O}_{2}(\mathrm{Cu} / \mathrm{Zn}-\mathrm{SOD}$ and $\mathrm{Fe}-\mathrm{SOD}$ inhibitor).

\subsection{CAT assay}

CAT activity was determined as described by Monteiro et al. (2011), with some minor modifications. CAT activity was assayed spectrophotometrically at $25^{\circ} \mathrm{C}$ in a reaction mixture containing $1 \mathrm{~mL} 100 \mathrm{mM}$ potassium phosphate buffer ( $\mathrm{pH}$ 7.5), containing $2.5 \mu \mathrm{L} \mathrm{H}_{2} \mathrm{O}_{2}$ (30\% solution) prepared immediately before use. The reaction was initiated by the addition of $15 \mu \mathrm{L}$ of plant extract and activity determined by monitoring the degradation of $\mathrm{H}_{2} \mathrm{O}_{2}$ at $240 \mathrm{~nm}$ over 1 min against a plant extract-free blank. CAT activity

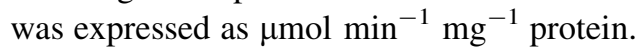

\subsection{APX assay}

APX activity was determined by the method of Cia et al. (2012), by monitoring the rate of ascorbate (AsA) oxidation at $290 \mathrm{~nm}$ at $30{ }^{\circ} \mathrm{C}$. The reaction medium contained $50 \mathrm{mM}$ phosphate buffer, $\mathrm{pH}$ 7.0, $0.5 \mathrm{mM}$ AsA, $0.1 \mathrm{mM}$ EDTA, $0.1 \mathrm{mM} \mathrm{H}_{2} \mathrm{O}_{2}$ and $100 \mu \mathrm{L}$ of enzyme extract, in a $1 \mathrm{~mL}$ of total volume. The reaction was started by the addition of AsA. The decrease in absorbance was followed from 10 to $60 \mathrm{~s}$ and APX activity was expressed as $\mu \mathrm{mol}$ AsA $\min ^{-1} \mathrm{mg}^{-1}$ protein.

\subsection{GPOX assay}

GPOX activity was determined as described by Gratão et al. (2012). The reaction medium contained $250 \mu \mathrm{L}$ phosphate-citrate buffer (sodium phosphate dibasic $0.2 \mathrm{M}$ : citric acid $0.1 \mathrm{M}$ ) $\mathrm{pH} 5.0,150 \mu \mathrm{L}$ enzyme 
extract and $25 \mu \mathrm{L} 0.5 \%$ guaiacol, which was vortex shaken and incubated at $30{ }^{\circ} \mathrm{C}$ for $15 \mathrm{~min}$. The reaction was stopped by quickly cooling in an ice-water bath, followed by the addition of $25 \mu \mathrm{L}$ of sodium metabisulphide $2 \%$ solution. The reaction mixture was held for $10 \mathrm{~min}$ and the GPOX activity was evaluated by monitoring the absorbance at $450 \mathrm{~nm}$. One enzyme activity unit (u) corresponds to an increase of 0.001 in absorbance per min.

\subsection{Statistical analysis}

The data was submitted to analysis of variance using the SAS program of statistics, System for Windows 6.11 (SAS Inst. 1996). According to the F test significance level for the treatments ( $\mathrm{N}$ levels and periods of evaluation), the data was submitted to linear and quadratic regression analysis using the GLM (general linear model) and the Tukey test (0.05) for mean comparisons. The correlations among dependent variables (leaf nitrogen, net photosynthesis, SOD, CAT, APX, and GPOX activity) were obtained by means of CORR procedure (Pearson correlation coefficient), using the SAS-System for Windows 6.11 (SAS Inst. 1996).

\section{Results}

\subsection{SOD activity}

SOD activity staining following non-denaturing PAGE revealed the existence of three bands in coffee leaves, including two Mn-SOD and one Fe-SOD (Fig. 1). The SOD bands were classified according to their metal co- factor based on their inhibitory pattern to hydrogen peroxide and/or potassium cyanide. A $\mathrm{Cu} / \mathrm{Zn}-\mathrm{SOD}$ inhibited by both compounds was not detected. SOD activity staining revealed two major Mn-SOD isoenzymes, I and II (resistant to both inhibitors), and a SOD isoenzyme III, classified as Fe-SOD (inhibited by hydrogen peroxide) as shown in Fig. 1.

SOD activity was enhanced significantly in coffee plants under $\mathrm{N}$ deficiency during fruit development (Fig. 2a). Moreover, bands I and II (Mn-SOD)

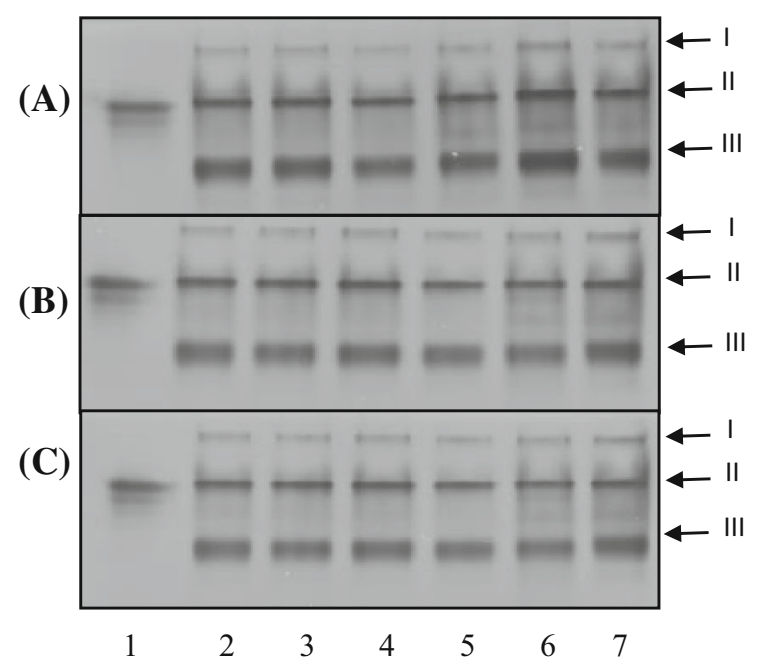

Fig. 2 Activity staining for SOD determined in coffee leaves extracts at different stages of fruits development, under nondenaturating conditions (PAGE $9 \%$ ). a Low $\mathrm{N}=$ absence of $\mathrm{N}$ $\left(0 \mathrm{~kg} \mathrm{~N} \mathrm{ha}^{-1}\right)$; b medium $\mathrm{N}=150 \mathrm{~kg} \mathrm{~N} \mathrm{ha}^{-1}$ and $\mathbf{c}$ high $\mathrm{N}=300 \mathrm{~kg} \mathrm{~N} \mathrm{ha}^{-1}$. The lines listed are: (1) bovine SOD standard, (2) pinhead-drop, (3) rapid expansion, (4) ripening, (5) green, (6) cherry and (7) dried fruits. The SOD isoforms are I Mn-SOD, II Mn-SOD; III Fe-SOD

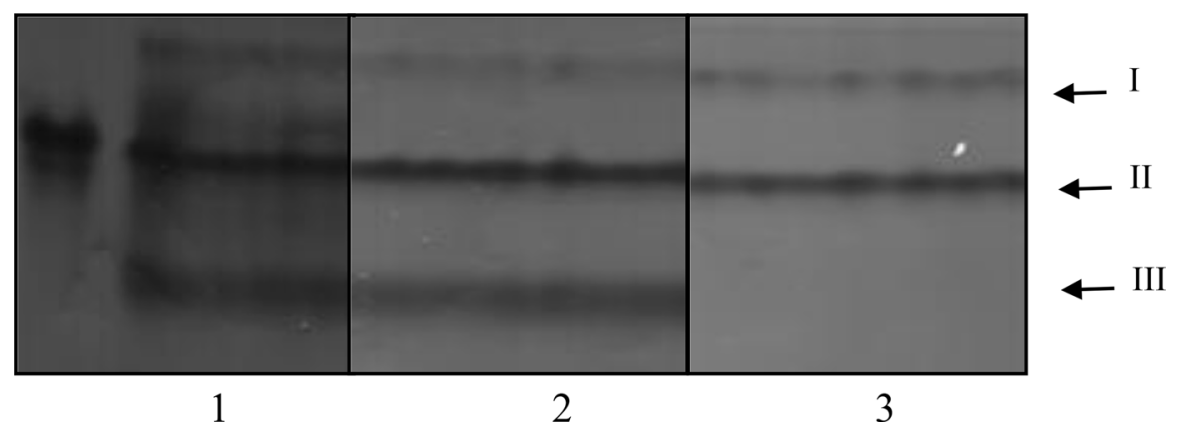

Fig. 1 Isoforms of SOD determined under non-denaturating conditions (PAGE $9 \%$ ) in coffee leaves extracts. Lane 1 pre incubating gel in revelation buffer without any inhibitor; lane 2 revelation buffer plus $2 \mathrm{mM}$ potassium cyanide $(\mathrm{Cu} / \mathrm{Zn}-\mathrm{SOD}$ inhibitor) and lane 3 revelation buffer plus $5 \mathrm{mM}$ hydrogen peroxide $(\mathrm{Cu} / \mathrm{Zn}-\mathrm{SOD}$ and $\mathrm{Fe}-\mathrm{SOD}$ inhibitor). The SOD isoforms are $I \mathrm{Mn}-\mathrm{SOD}$, II Mn-SOD; III Fe-SOD 
(A)

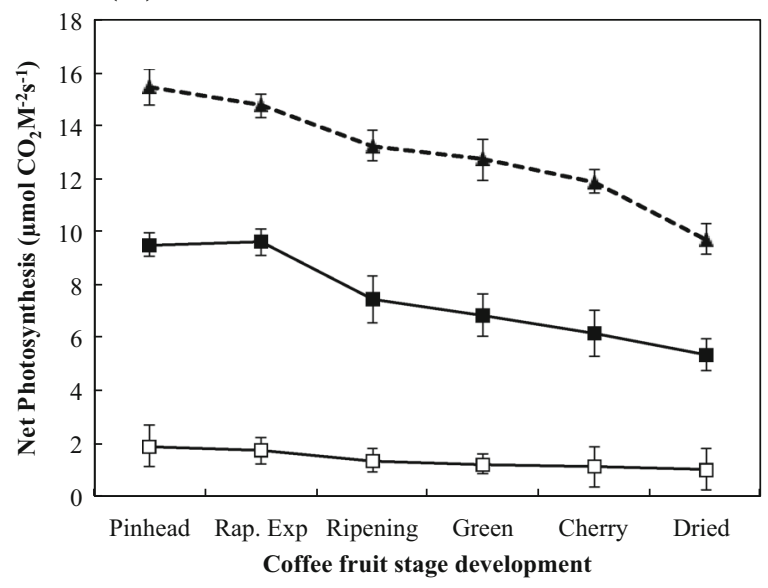

(C)

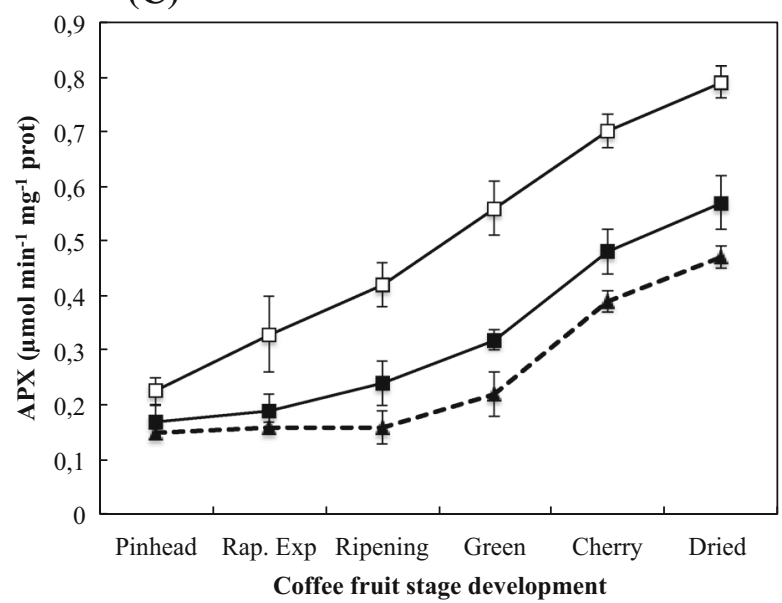

Fig. 3 Photosynthesis (a); CAT specific activity ( $\mu \mathrm{mol} \mathrm{min}^{-1}$

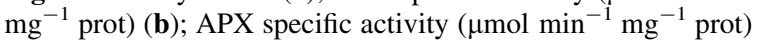
(c) and GPOX (u) (d) in coffee leaves during fruits development in response to $\mathrm{N}$ supply. Low $\mathrm{N}=0 \mathrm{~kg} \mathrm{ha}^{-1}$ (open square);

increased the intensity, as well as the thickness of bands of SOD on the native gels of coffee leaves under $\mathrm{N}$ deficiency (Fig. 2a, Lane 1-6). In addition, the band III (Fe-SOD) also increased, mainly in line 6-7 in all $\mathrm{N}$ treatment but specially in $\mathrm{N}$-deprived plants, and its activity is higher than the others two (Fig. 2). These results showed that bands of $\mathrm{Mn}-$ SOD and Fe-SOD, indicating that possibly more active in ROS production in $\mathrm{N}$-deficient coffee plants than chloroplasts in every stage of fruit development.
(B)

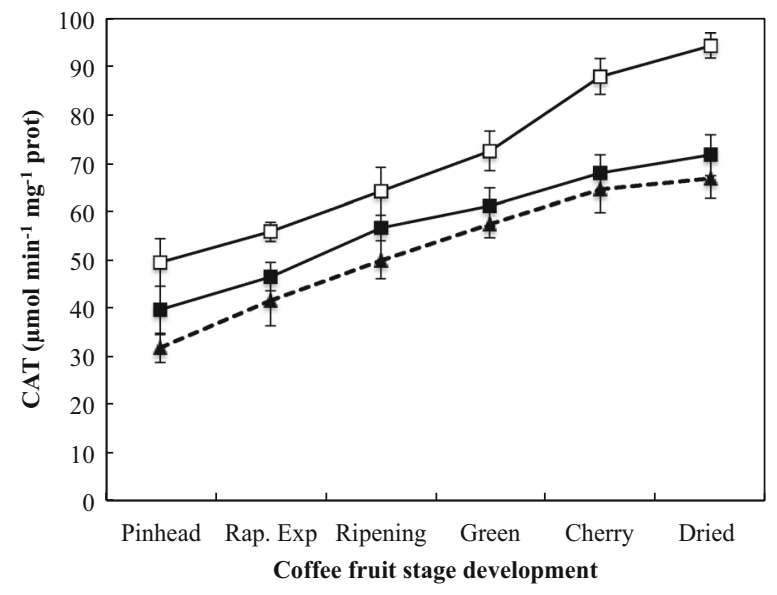

(D)

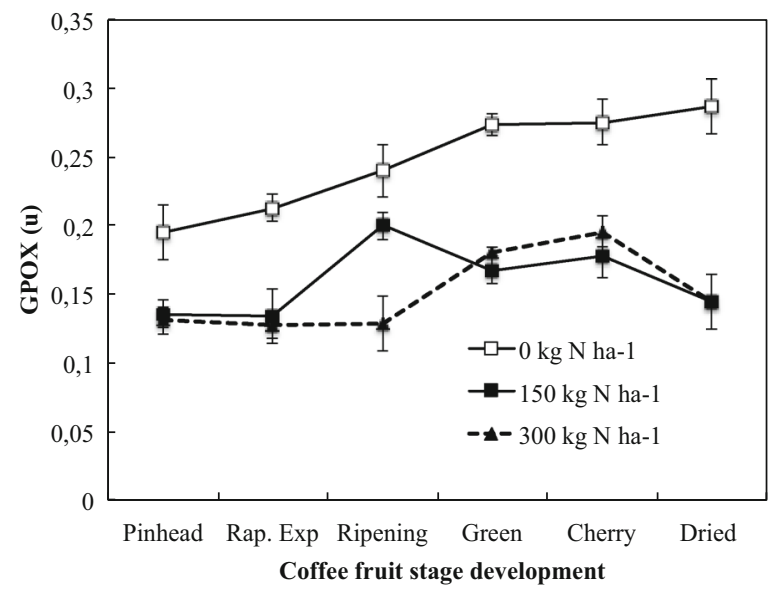

medium $\mathrm{N}=150 \mathrm{~kg} \mathrm{ha}^{-1} \quad$ (filled square) and high $\mathrm{N}=300 \mathrm{~kg} \mathrm{ha}^{-1}$ (filled triangle). Values are the means of five replicates \pm SEM. Rap. Exp Rapid Expansion

\subsection{Photosynthesis and antioxidant enzyme activities}

Photosynthetic rates in coffee leaves increased significantly with leaf $\mathrm{N}$ concentration until critical $\mathrm{N}$ values have been reached, after which photosynthetic rates remained constant despite further increases in $\mathrm{N}$ (Fig. 3a). Photosynthetic rates exhibited decreases in all treatments during fruit development until the end of the experiment (Fig. 3a). Nitrogen deficiency increased the activities of CAT, APX and GPOX 
Table 1 Relationship among levels of $\mathrm{N}\left(\mathrm{kg} \mathrm{ha}^{-1}\right)$, CFDE (coffee fruit developmental stage), TSP (total soluble protein, $\left.\mathrm{mg} \mathrm{mL}{ }^{-1}\right)$, GPOX (u), CAT ( $\mu \mathrm{mol} \mathrm{min}{ }^{-1} \mathrm{mg}^{-1}$ prot), APX

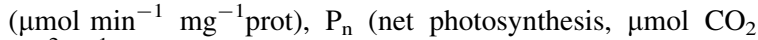
$\mathrm{m}^{-2} \mathrm{~s}^{-1}$ ), Chl (total chlorophyll, mg g-FW), and leaf $\mathrm{N}$ $\left(\mathrm{g} \mathrm{kg}^{-1}\right)$ in response to $\mathrm{N}$ supply

\begin{tabular}{|c|c|c|c|c|c|c|c|c|c|}
\hline & Levels & CFDE & TSP & GPOX & CAT & APX & Photo & Chl & $\mathrm{N}$ \\
\hline Levels & 1 & ns & $0.75^{*}$ & $-0.72 *$ & $-0.48^{*}$ & $-0.53 *$ & $0.96 *$ & $0.90 *$ & $0.90 *$ \\
\hline CFDE & & 1 & $-0.47 *$ & $0.32 * *$ & $0.84 *$ & $0.80 *$ & ns & ns & ns \\
\hline TSP & & & 1 & $-0.76^{*}$ & $-0.77 *$ & $-0.76^{*}$ & $0.87 *$ & $0.93 *$ & $0.87 *$ \\
\hline GPOX & & & & 1 & $0.72 *$ & $0.67 *$ & $-0.75^{*}$ & $-0.81 *$ & $-0.80 *$ \\
\hline CAT & & & & & 1 & $0.95 *$ & $-0.65^{*}$ & $-0.68 *$ & $-0.67 *$ \\
\hline APX & & & & & & 1 & $-0.68 *$ & $-0.69^{*}$ & $-0.70 *$ \\
\hline Photo & & & & & & & 1 & $0.95^{*}$ & $0.94 *$ \\
\hline Chl & & & & & & & & 1 & $0.96^{*}$ \\
\hline $\mathrm{N}$ & & & & & & & & & 1 \\
\hline
\end{tabular}

$n s$ Not significant

*** Significant at 1 and $5 \%,(\mathrm{p}<\mathrm{F} 0.0001)$

determined by the spectrophotometer assays (Fig. 3bd). These results indicated a clear inverse relationship between antioxidant enzymes activities and levels of $\mathrm{N}$ applied in coffee plants during fruit developmental stages (Table 1). The levels of $\mathrm{N}$ induced a different behavior in antioxidant enzyme activities, which was more active in N-deficient plants, and then continuously to increase during coffee fruit maturation.

\subsection{Nitrogen, chlorophyll and protein content}

From pinhead drop up to the dried fruit stage of development, fluctuation of total $\mathrm{N}$ concentration, total soluble protein and chlorophyll concentration were measured in coffee leaves (Fig. 4). A eightfold amplitude between the extreme values was observed during fruit development and a break down of leaf pigments was observed (Fig. 4c). In addition, total leaf $\mathrm{N}$, chlorophyll content and total soluble protein decreased in all treatments as shown in Fig. 4.

\section{Discussion}

\subsection{Photosynthesis and antioxidant responses to $\mathrm{N}$ supply}

$\mathrm{N}$ supply usually affects the plant biomass, metabolism, regulation, structure and crop production (Lawlor et al. 2001; Reis et al. 2009a; Ker et al. 2014).
Understanding the mechanisms by which crops respond to $\mathrm{N}$ is the key to maintaining and improving crop growth and yield, and the efficiency with which $\mathrm{N}$ is used and other resources as well (Da Matta et al. 1999, 2008; Reis et al. 2009b).

It has been suggested that in $\mathrm{N}$-deficient plants the primary targets of $\mathrm{N}$ limitations are the meristems, leading to the well characterized down regulation of photosynthetic activity in source leaves (Logan et al. 1999). The surplus electron flow could enhance oxygen photoreduction in the chloroplast via the Mehler reaction (Asada 1999; Roberty et al. 2014) leading to the production of elevated levels of reduced oxygen species. In this case, one might also expect chloroplasts of $\mathrm{N}$-deficient plants exhibit elevated activities of antioxidant enzymes such as SOD and APX, since these constituents are involved in the detoxification of reduced ROS (Polessakaya et al. 2006). As shown in the results, the coffee leaves submitted to $\mathrm{N}$ deficiency showed optimum activity of all enzymes antioxidants analyzed, however, in the case of SOD, this increase is due to the Mn-SOD and $\mathrm{Fe}-\mathrm{SOD}$ isoforms especially in lines $6-7$ in $\mathrm{N}$-deprived plants. ROS are continuously produced even under optimum growth conditions being important in leaf expansion and root growth of maize, making it possible the increase of some antioxidant enzyme activities that degrade $\mathrm{H}_{2} \mathrm{O}_{2}$ (Rodrigues et al. 2002; Polessakaya et al. 2004). Under conditions of prolonged stress, enhanced generation of ROS disturbs 

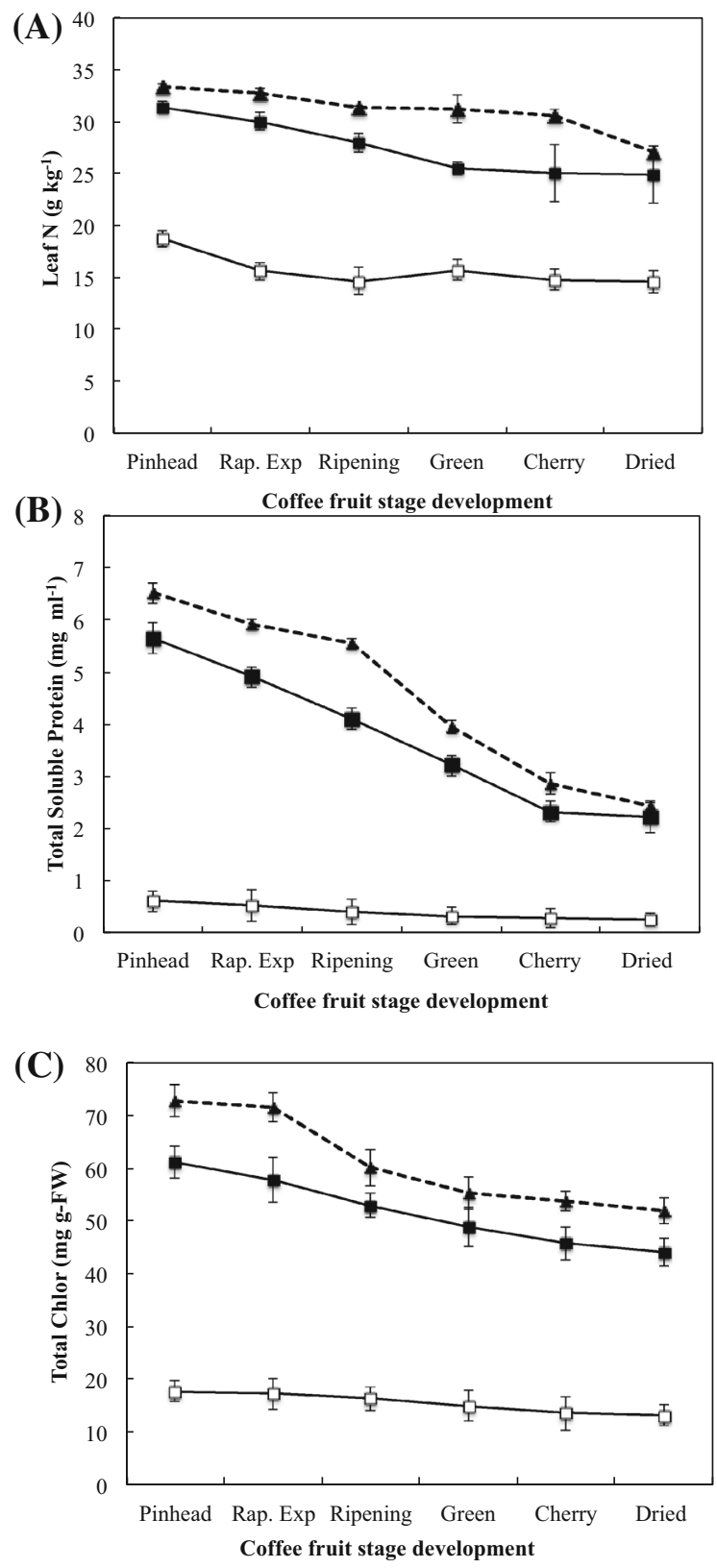

Fig. 4 Leaf $\mathrm{N}$ content (a); total soluble protein (b); and total chlorophyll content (c) in coffee leaves during fruits development in response to $\mathrm{N}$ supply. Low $\mathrm{N}=0 \mathrm{~kg} \mathrm{ha}^{-1}$ (open square); medium $\mathrm{N}=150 \mathrm{~kg} \mathrm{ha}^{-1}$ (filled square) and High $\mathrm{N}=300 \mathrm{~kg} \mathrm{ha}^{-1}$ (filled triangle). Values are the means of five replicates $\pm \mathrm{SEM}$

the normal redox environment of cells (Foyer and Noctor 2012; Keunen et al. 2013).

In coffee leaves and during leaf expansion fruit developmental stages, antioxidant enzymes such as
CAT, APX and GPOX were shown to increase in activity, mainly in $\mathrm{N}$-deficient plants, as shown in Fig. 3b-d, corroborating the previous report by Logan et al. (1999) and Huang et al. (2004) who observed increases in the activities of antioxidant enzymes in $\mathrm{N}$-deficient spinach and rice plants, respectively. Increases in the activities of CAT, APX and GPOX relate well with the increased $\mathrm{H}_{2} \mathrm{O}_{2}$ concentration in $\mathrm{N}$-deficient plants (Foyer and Noctor 2013). Since over $90 \%$ of total leaf APX activity and approximately $80 \%$ of total GR activity are localized in the chloroplast in plants grown under favorable conditions (Alscher et al. 1997), these trends for foliar APX and GR levels presumably represent a predominant chloroplastidic response (Logan et al. 1999).

The enzyme SOD is unique in that its activity can affect the $\mathrm{O}^{-2}$ radical, cell singlet oxygen and $\mathrm{H}_{2} \mathrm{O}_{2}$ concentrations (Foyer and Noctor 2013). The number of isoenzymes of each type of SOD varies greatly among plant species (Gratão et al. 2005) and we have been able to identify and classify up to three distinct SOD isoenzymes in coffee leaves. SOD activity, observed in coffee N-deficient plants, increased during fruit development as shown by the increased in SOD bands intensity on native gels (Fig. 2-lane 5). ROS generation may be further accentuated by limiting $\mathrm{CO}_{2}$ uptake efficiency and accumulating reducing power in N-deficient plants can be due to accumulation of $\mathrm{H}_{2} \mathrm{O}_{2}$, which is known to decrease stomatal opening (Neill et al. 2002).

The high SOD activity may suggest that enhanced $\mathrm{O}^{-2}$ radical generation during photosynthesis in leaves of the N-deficient plants occurred and the identification of the distinct classes of SOD isoenzymes indicates their likely cellular organelle location (Azevedo et al. 1998; Lee and Lee 2000; Vitória et al. 2001; Gratão et al. 2005; Gomes-Junior et al. 2007; Tezotto et al. 2012). Two bands of Mn-SOD exhibited increases in activity in coffee leaves during fruit development in response to $\mathrm{N}$ supply (Fig. 1). One band of Fe-SOD isoenzyme activity exhibiting very low activity has also been observed following electrophoresis, but they remained essentially constant without any major changes during fruit ripening stage. $\mathrm{Fe}-\mathrm{SOD}$ isoenzymes have been detected in plants, but not to the same extent as Mn-SODs, and have been shown to be associated with chloroplasts (Vitória et al. 2001; Gomes-Junior et al. 2007). The chloroplasts of the coffee plants, in this study, apparently were not majorly exposed to ROS, since that other SOD 
isozyme (Mn-SOD), resident in the mitochondria, proved to be more active (Figs. 1,2). The decrease on net photosynthesis can be partially attributed to other factors rather than the direct overproduction of ROS in the chloroplasts in response to $\mathrm{N}$ starvation, such as low chlorophylls content (Fig. 4).

In conclusion, alteration in activated oxygen metabolism was detected by increases of CAT, APX, GPOX and SOD activities during leaf nutrient remobilization to coffee fruits particularly in $\mathrm{N}$-deficient coffee plants. $\mathrm{Cu} / \mathrm{Zn}-\mathrm{SOD}$ isoenzymes were not detected in coffee leaves, whereas two bands of $\mathrm{Mn}-$ SOD, sited in mitochondria, exhibited increases in activity in coffee leaves during fruit development in response to $\mathrm{N}$ supply. Net photosynthesis, leaf $\mathrm{N}$ concentration and total protein content increased in response to $\mathrm{N}$ supply. Our results suggest that the relationship between the increased leaf antioxidant enzyme activities and $\mathrm{N}$ nutritional status during fruit development indicated that the antioxidant system is very active during the coffee fruit ripening stage.

Acknowledgments ARR, JLF and RAA thanks to Fundação de Amparo à Pesquisa do Estado de São Paulo (FAPESP, Brazil: Grant no. 06/54552-0) for fellowship and financial support.

\section{References}

Alscher RG, Donahue JL, Cramer CL (1997) Reactive oxygen species and antioxidants: relationships in green cells. Physiol Plant 100:224-233

Alscher RG, Erturk N, Heath LS (2002) Role of superoxide dismutases (SODs) in controlling oxidative stress in plants. J Exp Bot 53:1331-1341

Andrews M, Raven JA, Sprent JI, Lea JP (2007) Is shoot growth correlated to leaf protein concentration? Trends Plant Sci 12:531-532

Andrews M, Lea PJ, Raven JA, Azevedo RA (2009) Nitrogen use efficiency. 3. Nitrogen fixation: genes and costs. Ann Appl Biol 155:1-13

Andrews M, Edwards GR, Ridway HJ, Cameron KC, Di HJ, Raven JA (2011) Positive plant microbial interactions in perennial ryegrass dairy pasture systems. Ann Appl Biol 159:79-92

Andrews M, Raven JA, Lea PJ (2013) Do plants need nitrate? The mechanisms by which nitrogen form affects plants. Ann Appl Biol 165:1-26

Arnon DI (1949) Cooper enzymes in isolated chloroplasts, polyphenoloxidase in Beta vulgaris. Plant Physiol 24:1-15

Asada K (1999) The water-water cycle in chloroplasts: scavenging of active oxygen and dissipation of excess photons. Annu Rev Plant Phys 50:601-639
Azevedo RA, Alas RM, Smith RJ, Lea PJ (1998) Response of antioxidant enzymes to transfer from elevated carbon dioxide to air and ozone fumigation, in the leaves and roots of wild-type and a catalase-deficient mutant of barley. Physiol Plant 104:280-292

Barros RS, Maestri M, Rena AB (1999) Physiology of growth and production of the coffee tree. J Coffee Res 27:1-54

Bradford MM (1976) A rapid and sensitive method for the quantitation of microgram quantities of protein utilizing the principle of protein-dye binding. Anal Biochem 72:248-254

Camargo ER, Marchesan E, Rossato TL, Grohs M, Sartori GMS, Ferreira RB (2011) Effect of nitrogen and fungicide application during the booting stage of rice on duration and rate of dry mass accumulation of grains. R Bras Agroc 17:420-427

Carswell FE, Millard P, Rogers GND, Whitehead D (2003) Influence of nitrogen and phosphorus supply on foliage growth and internal recycling of nitrogen in conifer seedlings (Prumnopitys ferruginea). Funct Plant Biol 30:49-55

Carvalho RF, Takaki M, Azevedo RA (2011) Plant pigments: the many faces of light perception. Acta Physiol Plant 33:241-248

Cassano LM, Martin M, Sabater B (1994) Sensitivity of superoxide dismutase transcript levels and activities of oxidative stress is lower in mature-senescent than in young barley leaves. Plant Physiol 106:1033-1039

Chen JW, Yang ZQ, Zhou P, Hai MR, Tang TX, Liang YL (2013) Biomass accumulation and partitioning, photosynthesis, and photosynthetic induction in field-grown maize (Zea mays L.) under low and high nitrogen conditions. Acta Physiol Plant 35:95-105

Cia MC, Guimarães ACR, Medici LO, Chabregas SM, Azevedo RA (2012) Antioxidant responses to water deficit by drought-tolerant and sensitive sugarcane varieties. Ann Appl Biol 161:313-324

Da Matta FM, Amaral JAT, Rena AB (1999) Growth periodicity in trees of Coffea arabica in relation to nitrogen supply and nitrate reductase activity. Field Crop Res 60:223-229

Da Matta FM, Loos RA, Silva EA, Loureiro ME, Ducatti C (2002) Effects of soil water deficit and nitrogen nutrition on water relations and photosynthesis of pot-grown Coffea canephora Pierre. Trees 16:555-558

Da Matta FM, Cunha RL, Antunes WC, Martins SV, Araujo WL, Fernie A, Moraes GABK (2008) In field-grown coffee trees source-sink manipulation alters photosynthetic rates, independently of carbon metabolism, via alterations in stomatal function. New Phytol 178:348-357

del Río LA, Sandalio LM, Altomare DA, Zilinskas BA (2003) Mitochondrial and peroxisomal manganese superoxide dismutase: differential expression during leaf senescence. J Exp Bot 54:923-933

Demming-Adams B, Adams WW, Baker DH, Logan BA, Bowling BR, Verhoeven AS (1996) Using chlorophyll fluorescence to assess the fraction of absorbed light allocated to thermal dissipation of excess excitation. Physiol Plant 98:253-264

Dourado MN, Martins PF, Quecine MC, Piotto FA, Souza LA, Franco MR, Tezotto T, Azevedo RA (2013) Burkholderia sp. SCMS54 reduces cadmium toxicity and promotes growth in tomato. Ann Appl Biol 163:494-507 
Fenilli TAB, Reichardt K, Dourado-Neto D, Trivelin PCO, Favarin JL, Costa FMP, Bacchi OOS (2007) Growth, development, and fertilizer- ${ }^{15} \mathrm{~N}$ recovery by the coffee plant. Sci Agric 64:541-547

Fidalgo F, Santos A, Santos I, Salema R (2004) Effects of long term salt stress on antioxidant defense systems, leaf water relations and chloroplast ultrastructure of potato plants. Ann Appl Biol 145:185-192

Foyer CH, Noctor G (2012) Managing the cellular redox hub in photosynthetic organisms. Plant, Cell Environ 35:199-201

Foyer CH, Noctor G (2013) Redox signaling in plants. Antioxid Redox Signal 18:2087-2090

Garcia JS, Gratão PL, Azevedo RA, Arruda MAZ (2006) Metal contamination effects on sunflower (Helianthus annus L.) growth and protein expression in leaves during development. J Agric Food Chem 54:8623-8630

Ghelfi A, Gaziola SA, Cia MC, Chabregas SM, Falco MC, Kuser-Falcão PR, Azevedo RA (2011) Cloning, expression, molecular modelling and docking analysis of glutathione transferase from Saccharum officinarum. Ann Appl Biol 159:267-280

Gill SS, Hasanuzzaman M, Nahar K, Macovei A, Tuteja N (2013) Importance of nitric oxide in cadmium stress tolerance in crop plants. Plant Physiol Bioch 63:254-261

Gomes-Junior RA, Gratão PL, Gaziola SA, Mazzafera P, Lea PJ, Azevedo RA (2007) Selenium-induced oxidative stress in coffee cell suspension cultures. Funct Plant Biol 34:449-456

Gratão PL, Polle A, Lea PJ, Azevedo RA (2005) Making the life of heavy metal-stressed plants a little easier. Funct Plant Biol 32:481-494

Gratão PL, Monteiro CC, Carvalho RF, Tezotto T, Piotto FA, Peres LEP, Azevedo RA (2012) Biochemical dissection of diageotropica and Never ripe tomato mutants to $\mathrm{Cd}$ stressful conditions. Plant Physiol Bioch 56:79-96

Gratão PL, Monteiro CC, Tezotto T, Carvalho RF, Alves LR, Peters LP, Azevedo RA (2015) Cadmium stress antioxidant responses and root-to-shoot communication in grafted tomato plants. Biometals 28:803-816

Huang ZA, Jiang DA, Yang Y, Sun JW, Jin SH (2004) Effects of nitrogen deficiency on gas exchange, chlorophyll fluorescence, and antioxidant enzymes in leaves of rice plants. Photosynthetica 42:357-364

Ker K, Seguin P, Driscoll BT, Fyles JW, Smith DL (2014) Evidence for enhanced $\mathrm{N}$ availability during switchgrass establishment and seedling year production following inoculation with rhizosphere endophytes. Arch Agron Soil Sci 60:1553-1563

Keunen E, Peshev D, Vangronsveld J, Ende WV, Cuypers A (2013) Plant sugars are crucial players in the oxidative challenge during abiotic stress. Extending the traditional concept. Plant, Cell Environ 36:1242-1255

Kováčik J, Bačkor M (2007) Changes of phenolic metabolism and oxidative status in nitrogen-deficient Matricaria chamomilla plants. Plant Soil 297:255-265

Lawlor DW, Lemaire G, Gastal F (2001) Nitrogen, plant growth and crop yield. In: Lea PJ, Morot-Gaudry JF (eds) Plant nitrogen. Springer, Berlin, pp 343-367

Lea PJ, Azevedo RA (2006) Nitrogen use efficiency. 1. Uptake of nitrogen from the soil. Ann Appl Biol 149:243-247

Lea PJ, Azevedo RA (2007) Nitrogen use efficiency. 1. Amino acid metabolism. Ann Appl Biol 151:269-275
Lee DH, Lee CB (2000) Chilling stress-induced changes of antioxidant enzymes in the leaves of cucumber: in-gel enzyme activity assays. Plant Sci 159:75-85

Logan BN, Demmig-Adams B, Rosenstiel TN, Adams WW (1999) Effect of nitrogen limitation on foliar antioxidants in relationship to other metabolic characteristics. Planta 209:213-220

Majerowicz N, Pereira JMS, Medici LO, Bison O, Pereira MB, Moreira Junior U (2002) Nitrogen use efficiency in local and improved maize varieties. Braz J Bot 25:29-136

Medici LO, Azevedo RA, Smith RJ, Lea PJ (2004) The influence of nitrogen supply on antioxidant enzymes in plant roots. Funct Plant Biol 31:1-9

Monteiro CC, Carvalho RF, Gratão PL, Carvalho G, Tezotto T, Medici LO, Peres LEP, Azevedo RA (2011) Biochemical responses of the ethylene-insensitive Never ripe tomato mutant subjected to cadmium and sodium stress. Environ Exp Bot 71:306-320

Neill S, Desikan R, Hancock J (2002) Hydrogen peroxide signaling. Curr Opin Plant Biol 5:388-395

Neto AP, Favarin JL, Almeida REM, Dias CTS, Tezotto T, Alves ALG, Moraes MF (2011) Changes of nutritional status during a phenological cycle of coffee under high nitrogen supply by fertigation. Commun Soil Sci Plan 42:2414-2425

Neto AP, Favarin JL, Reis AR, Tezotto T, Almeida REM, Lavres J Jr, Gallo LZ (2015) Nitrogen metabolism in coffee plants in response to nitrogen supply by fertigation. Theor Exp Plant Physiol 27:41-50

Netto AT, Campostrini E, Oliveira JG, Bressan-Smith RE (2005) Photosynthetic pigments, nitrogen, chlorophyll a fluorescence and SPAD-502 readings in coffee leaves. Sci Hortic 104:199-209

Polessakaya OG, Kashirina EI, Alekhina ND (2004) Changes in the activity of antioxidant enzymes in wheat leaves and roots as a function of nitrogen source and supply. Russ J Plant Physiol 51:615-620

Polessakaya OG, Kashirina EI, Alekhina ND (2006) Effect of salt stress on antioxidant system of plants as related to nitrogen nutrition. Russ J Plant Physiol 53:186-192

Pompelli MF, Martins SCV, Antunes WC, Chaves ARM, DaMatta FM (2010) Photosynthesis and photoprotection in coffee leaves affected by nitrogen and light availabilities in winter conditions. J Plant Physiol 167:1052-1060

Ray D, Sheshayee MS, Mukhopadhyay K, Bindumadhava H, Prasad TG, Kumar MU (2003) High nitrogen use efficiency in rice genotypes is associated with higher net photosynthetic rate at lower Rubisco content. Biol Plant 46:251-256

Reis AR, Furlani Junior E, Buzetti S, Andreotti M (2006) Diagnosis of $\mathrm{N}$ requirements for coffee plant using a portable chlorophyll meter. Bragantia 65:163-171

Reis AR, Favarin JL, Gallo LA, Malavolta E, Moraes MF, Lavres Junior J (2009a) Nitrate reductase and glutamine synthetase activity in coffee leaves during fruit development. R Bras Ciênc Solo 33:315-324

Reis AR, Favarin JL, Malavolta E, Lavres Junior J, Moraes MF (2009b) Photosynthesis, chlorophylls and SPAD readings in coffee leaves in relation to nitrogen supply. Commun Soil Sci Plant Anal 40:1512-1528

Reis AR, Favarin JL, Gallo LA, Moraes MF, Tezotto T, Lavres Junior J (2011) Influence of nitrogen fertilization on nickel 
accumulation and chemical composition of coffee plants during fruit development. J Plant Nutr 34:1853-1866

Rendón MY, Gratão PL, Salva TJG, Azevedo RA, Bragagnolo N (2013) Antioxidant enzyme activity and hydrogen peroxide content during the drying of Arabica coffee beans. Eur Food Res Technol 236:753-758

Resende ECO, Martins PF, Azevedo RA, Jacomino AP, Bron IU (2012) Oxidative processes during "Golden" papaya fruit ripening. Braz J Plant Physiol 24:85-94

Roberty S, Bailleul B, Berne N, Franck F, Cardol P (2014) PSI Mehler reaction is the main alternative photosynthetic electron pathway in Symbiodinium sp., symbiotic dinoflagellates of cnidarians. New Phytol 204:81-91

Rodrigues AA, Grunber KA, Taleisnik EL (2002) Reactive oxygen species in the elongation zone of maize leaves are necessary for leaf extension. Plant Physiol 129:1627-1632
SAS Institute. SAS/STAT (1996) 'User's guide, version 6.11.' 4th ed SAS Institute Inc., Cary

Su Y, Liu J, Lu Z, Wang X, Zhang Z, Shi G (2014) Effects of iron deficiency on subcellular distribution and chemical forms of cadmium in peanut roots in relation to its translocation. Environ Exp Bot 97:40-48

Tezotto T, Favarin JL, Azevedo RA, Alleoni LRF, Mazzafera P (2012) Coffee is highly tolerant to cadmium, nickel and zinc: plant and soil nutritional status, metal distribution and bean yield. Field Crop Res 125:25-34

Vitória AP, Lea PJ, Azevedo RA (2001) Antioxidant enzymes responses to cadmium in radish tissues. Phytochemistry 57:701-710 